\title{
Gender, Religion, and Political Agency: Mapping the Field
}

Género, religião e ação política: cartografia da área

Genre, religion et action politique: cartographie du secteur

\section{Alberta Giorgi}

\section{OpenEdition}

\section{Journals}

Electronic version

URL: http://journals.openedition.org/rccs/6371

DOI: $10.4000 /$ rccs.6371

ISSN: 2182-7435

Publisher

Centro de Estudos Sociais da Universidade de Coimbra

Printed version

Date of publication: 1 September 2016

Number of pages: $51-72$

ISSN: 0254-1106

\section{Electronic reference}

Alberta Giorgi, «Gender, Religion, and Political Agency: Mapping the Field », Revista Crítica de Ciências Sociais [Online], 110 | 2016, Online since 26 September 2016, connection on 19 April 2019. URL : http:// journals.openedition.org/rccs/6371; DOI : 10.4000/rccs.6371 


\section{ALBERTA GIORGI}

\section{Gender, Religion, and Political Agency: Mapping the Field*}

This paper provides an introductory review of the literature mapping the gendered analyses of the categories of secularism and secularization from a sociological point of view, with the aim of providing some coordinates and bibliographical references and showing the theoretical and analytical implications of the gendered analyses of secularism in relation to the grammars of contemporary democracy. Firstly, it explores how a gendered analysis contributes to redefining the analytical concepts of secularism and secularization. Secondly, it highlights the contributions of women's, gender, and queer studies to the analysis of secularism and religion. Thirdly, it focuses on the tensions between women's and religious agency, showing how and to what extent the debate internal to the sociology of religion is in fact highly relevant to current sociological analyses.

Keywords: gender studies; politics; secularization; sociology of religion; women's rights.

\section{Introduction: Sexularism?}

This paper provides an introductory review of the literature mapping the gendered analyses of the categories of secularism and secularization from a sociological point of view, with the aim of providing some coordinates and bibliographical references and showing the theoretical and analytical implications of the gendered analyses of secularism in relation to the grammars of contemporary democracy.

When dealing with women's rights, equality and the deconstruction of gender roles, religion is often perceived as an obstacle. Indeed, many religious agents involved in the public debate take a firm stand against some typically feminist issues (such as voluntary termination of pregnancy, to mention but one) and against the concept of gender itself. In a brilliant

* Funding acknowledgements: this work was supported by the Fundação para a Ciência e a Tecnologia, under grant SFRH/BPD/77552/2011. 
synthesis, Joan Scott uses the word Sexularism to show the difficult, often unarticulated relationship between secularization, women's rights and gender equality (2009). Scott, who argues in favor of deconstructing this relationship, points out that, even if women's rights have been achieved primarily in secularized environments, from a historical point of view there is no necessary connection between secularization and the promotion of women's rights, nor between secularization and the promotion of equal rights. For this reason, the analysis of women's role in religion and of the contributions of religious feminism could offer an interesting approach to a further examination of the issue.

Interest in the "women and religion" theme has developed through various phases. In the "60s and "70s many European and North-American female researchers began to focus on the analysis of female religious experience, often starting from a feminist point of view internal to the most common religious traditions (see section 2). Studies and analyses on this topic evolved in an interdisciplinary perspective, involving mainly sociology, history of religions, and feminist studies. The "women and religions" theme has become increasingly appealing in the European academic world, especially since the second half of the '90s, and has moved beyond the disciplinary limits within which it was prevalently confined. This increasing resonance can be explained in various ways. Firstly, the issue of religion and its role and place in contemporary societies in general is attracting growing interest among non-specialized scholars, as is underlined by Beckford (1996 and 2000). Secondly, the experience and the role of women in religion became more relevant, especially when compared with non-Christian religious traditions in the context of migration. In a more general way, the influence of these factors can be placed within a much broader transformation in the theoretical apparatuses of the social sciences, alongside the development of specific interests in alterity, which contributed to the questioning of the implicit assumptions of the analytical categories used to analyze social processes. The main references are post-colonial, post-structuralist, gender and queer studies, and, more generally, all theoretical movements born within the discursive turn in the social sciences. Broadly speaking, these studies shed light on the plurality of the constructions of the male and female subject in various denominations as well as the plurality of religious experiences, both within traditional religions and in non-mainstream forms of religiosity that overturn gender hierarchy.

The weave of reflections briefly outlined above contributed to developing a specific interdisciplinary debate which, on the one hand, carefully analyzes women and religion and, on the other, invites deconstruction, historicization 
and contextualization of the categories 'religion' and 'gender identity'. Within this debate, one of the first works to be published with a specific focus on religion from a gender perspective ${ }^{1}$ was the volume Religion and Gender edited by Ursula King (1995). It collects analyses of the experiences of women and men and of the construction of the male and female subject in several religious traditions, along with a variety of theoretical considerations and interdisciplinary empirical studies. In her introduction King stressed the fact that, although in the " 70 s and ' 80 s studies on the female religious experience flourished, in the literature on religion there was yet neither a specific focus on male experience nor a gender perspective. In the following years, several studies were to fill this gap (see, for example, Castelli, 2001; Woodhead, 2001; Ruether, 2002; King and Beattie, 2004; Chewning, 2005; Deeb, 2006; Morin and Guelke, 2007; Rochefort, 2007a; Aune et al., 2008; Bracke, 2008a; Braidotti, 2008; Herzog and Braude, 2009; Mahamood, 2005; Phillips, 2009; Höpflinger et al., 2012). One of the first occasions where this topic was seriously addressed in Europe was the conference "Religion and Gender" organized by Linda Woodhead and others at Lancaster University in the context of the annual conference of the study group on religion of the British Sociological Association. In 2011, the network of male and female researchers that took part in the conference gave rise to the interdisciplinary and open access magazine Religion and Gender, and in 2015 to the International Association for the Study of Religion and Gender.

The present article is structured as follows: the next section focuses on the problematic aspects of secularization and secularism in dealing with the female religious experience; the third section traces the history of the analysis of the relationships between women, women's rights, gender identity, and religion; the fourth section discusses the more general theoretical implications of the literature dealing with the role of women in religion and claims that a gender approach to secularism and secularization is necessary for a deep reflection on political agency in contemporary democracies. Lastly, the fifth section points to a number of open questions.

\section{Secularization, Europe, and Gender Equality: Deconstructing the Necessary Relationship}

The first relevant aspect to consider in analyzing secularization and secularism from a gender point of view consists in questioning, by means of a historical analysis, whether there is a necessary relationship between the

\footnotetext{
${ }^{1}$ A gender perspective is in general the deconstruction, the historicization, and analysis of social and cultural meanings associated to sexual identity and to the relationship between genders.
} 
process of secularization and gender equality. Although in disagreement regarding the scope of the process and its consequences, most scholars agree that there has been a change in the social role of religion (Dobbelaere, 1985; Chaves, 1994; Casanova, 1994; Taylor, 2007). Moreover, during the long struggle for women's rights, from non-discrimination to equality, religious institutions and female and feminist movements were often on opposing sides. Even if the implicit, necessary relationship between secularism and democracy is questioned - hence the existence of secular non-democratic countries (Bhargava, 1998; Wohlrab-Shar, 2011) -, this rarely leads to a deconstruction of the relationship between secularism and women's rights. Speaking about the process of secularization, Joan Scott states that: "the equal status of women and men was not a primary concern for those who moved to separate church and state" (Scott, 2009: 1). In fact, reconstructing the historical process of the French laïcité - one of the main references in terms of secularization processes (Baubérot and Milot, 2011), Florence Rochefort shows how the first project to secularize the Republic had nothing to do with "reforms of the civil code, even if fragmentary, which could lift married women out of their minority status, equal to that of children, deranged people and criminals" (Rochefort, 2007b: 65). ${ }^{2}$ According to Rochefort, representations of the feminine were based on a sexual dichotomy: men, reason and power - and the public sphere on the one side, women, intuition and feeling - and the private sphere - on the other. Republican feminism was only one of the components, together with Catholic and conservative republicanisms; it was only during the Third Republic that republican feminism became a real movement for gender equality, also thanks to the cooperation between Protestant female philanthropy and secular activists. "It is the adversarial strategy of the Catholic opposition, especially regarding women and feminism, and its stigmatization of secularism, that awakened a more or less blurred discourse in defense of secularism. The rivalry of a Catholic feminism largely contributed to this turning point" (ibidem: 75). Thus it can be said that even in France the relationship between secularization and women's rights is a historical contingency and a political product of the competition between movement elites (McAdam et al., 2001). French secularism is only one among numerous 'cultures of secularity' (Wohlrab-Sahr and Burchardt, 2012). However, it is also regarded as a cultural point of reference, which

\footnotetext{
${ }^{2}$ As shown by the Declaration of the Rights of Woman and the Female Citizen by author Olympe De Gouges, which reports the scarce consideration for female citizenship on the part of the revolutionaries (All translations, unless otherwise specified, are my own).
} 
makes the historical analysis of its primary cultural objectives particularly relevant. More generally, and considering the history of the other European countries, the relationship between men-women equality and secularization has a complex and contradictory past.

The second element to emerge from a historical analysis of the secularization process is the narrative construction of modernity as opposed to religion and tradition, as well as the role of women in this narrative (Bracke, 2008b). Broadly speaking, in the literature secularism denotes the separation between secular and religious institutions, whilst social and individual secularization tends to indicate that the influence of religious organizations and institutions on politics has waned, that the important moments in life involve less and less religious rituals and symbols, that religious categories, faith and religious identity have less and less influence upon relationships, behavior, and individual attitudes. It also means that people do not attend religious services as frequently as they did in the past and that, in general, religious motivations for actions are less relevant than other types of motivations (Ferrara, 2009). In one of the first pieces of writing to explore the theme of secularization and women, Callum Brown (2001) exposed the gender bias of these general assumptions. Considering the empirical data on regular participation in religious services per sex, it appears that men's participation quickly decreased, whereas women's participation remained stable for a long time ('feminization' of religiosity). This means that:

Modern men's experiences are taken as the norm and model for the future of religion: when men leave religion, religion is said to be dying, regardless of its continuity in women's lives. [...] Often women's continued religiosity is viewed as marginal to the 'main event' of male secularization [...] women are positioned as the irrational others of secularizing modernity. [...] Women's experiences instead point to a different 'truth' about religiosity in contemporary times. (Aune et al., 2008: 5-6).

From this point of view, the meaning of the secularization process, the relevant historical period and the forms it takes should be reconsidered, taking the different experiences of men and women into account. ${ }^{3}$ The term of reference for the secularization process is the male experience of 'leaving' religion and 'entering' a new political place with a different function. Nonetheless, women, like religion, primarily inhabit the private space: women`s entry into the political sphere is made possible through a historical process whereby rights and emancipation are achieved.

3 The same could be said, for instance, in terms of social classes. 
Thus, women and religion are on the same side - the "wrong" side of the secularization process (Scott, 2009; Herzog and Braude, 2009). But women undergo a double exclusion: from the public/political sphere, and also from institutionalized religion, which is dominated by a male clergy. As is discussed in the following section, various studies of female religiosity emphasize the way in which such studies ended up influencing women's search for religious forms of expression that go beyond regular and simple participation in religious services.

Critiques of the identification of participation as an index of secularization have already become commonplace in the literature, which highlights the Christian- and European-centered nature of participation as well as its inability to capture forms of lived and everyday religiosity. According to Aune et al. (2008), there are several reasons why these criticisms are all the more relevant in the case of an analysis based on gender. First of all, in the Western Christian tradition women normally engage in popular and traditional forms of religiosity - often outside official religion ${ }^{4}$ - which are not measured by traditional signs of religious participation. Secondly, data on regular participation in religious services does not take into account the forms of alternative religiosity, such as new-age or new-pagan spirituality, where women are the majority (Helaas et al., 2005). If, then, religious participation is considered as a valid indication not only for Christianity but also for other monotheistic religious traditions, the issue becomes even more complicated: the hierarchy of religious obligations often differs for men and women. Lastly, some religious traditions forbid women from entering places of worship, in which case the lack of female participation in religious services could be interpreted as strict orthodoxy.

The historical analysis of the secularization process (which deconstructs all necessary relationships between secularization and gender equality), of its narrative construction (which shows how women, along with religion, came to be excluded), and of the female religious experience (in various and different forms) thus encourages us to rethink the secularization process from the point of view of the decline of religion and from the point of view of the separation of spheres and their relevant functions, given the long-time exclusion of women both from the public sphere and from the institutionalized part of the religious sphere.

\footnotetext{
${ }^{4}$ It is also important to keep in mind the feminist movements within institutionalized religions, especially within Christianity, which challenge the supremacy of men in the clergy. One example is the international Catholic association Women Can Be Priests! (http://www.womenpriests.org/) which organized a "pink smoke" in Rome during the election of Pope Francis to protest against the exclusion of women from priesthood.
} 


\section{The Analysis of Women's Relationship with Religion - What else does it tell us?}

While retracing the course of the literature on women and religion, it is important to bear in mind that for the most part it has sprung from the need to recognize the importance of the role played by women - with the purpose of showing the uniqueness of the female experience -, of analyzing the role of women in religion, of claiming equality between women and men, or of questioning gender inequality. For this reason, the sources of this re-examination are to be found in sociology and in the history of religions, in women and queer studies and in the history of feminism (Woodhead, 2001; Braidotti, 2008; Korte, 2011).

Concerning the history of feminism, its first wave, as pointed out by Woodhead, was characterized by strong criticism of institutionalized religions, which was accused of promoting the submission of women both on a practical and symbolic level (2001). In this context, historical feminism is mainly anti-clerical and rejects religious tradition as being part of the dominant structure. On the other hand, religious women's rights movements also emerge within Christianity, as is the case with the Catholic Société des féministes chrétiennes and the Protestant Mouvement Jeunes Femmes, which are at the root of feminist theology (see Forcades, 2015; Stanton, 1895 and 1898). Therefore, the relationship between the secularization process and historical feminism is a complex and ambivalent one. Furthermore, many left the Christian religion and converted to other forms of religiosity (Höpflinger et al., 2012). In the '60s and '70s, also in connection with the so-called second wave of feminism and the achieving of women's rights, there was a growing interest in those forms of religiosity which subverted the hierarchy between genders or which excluded men, such as some New Age movements, faiths based on the Goddess Earth and theories based on forms of primal matriarchy and on a privileged bond between women and nature. This has not necessarily to do with the denying of religion, but rather with the acknowledging of the proper value of forms of religiosity - especially female ones - both outside (see Woodhead, 2001) and within traditional religions (Saiving, 1979; McLaughin, 1975). In the meantime, within traditional religions, holy texts started to become the object of a critical re-reading. The Protestant female minister Brackenbury Crook (1964), for example, offered a feminist reanalysis of theology and the Bible, while the Catholic theologian Elisabeth Schüssler Fiorenza (1983), one of the female founders of the Journal of Feminist Studies in Religion, used a feminist perspective with a political and hermeneutical slant in her re-reading of holy texts. Feminism too is confronted with religion. Thus for example 
the books of the radical feminist Mary Daly (1973), who is deeply critical of what she calls the sexism of the Catholic Church, are well known. At the opposite end, other feminisms (e.g. black feminism in the USA) combined political activism with strong religiosity within traditional religions (Lorde, 1984; hooks, 1990). In this regard, mention should be made of the extremely inspiring development of womanist theology, with its focus on the construction of black womanhood and its attention to the role of religion in the experience of black women (Walker, 1983).

In the years that followed, the literature on this topic evolved and became more systematic, revolving around several key issues: the relationship between religion and women's rights, the relationship between 'West' and 'Islam' in the perspective of subaltern studies - leading to a reflection on the role of women in the Islamic religion and the relationship between religion and the construction of a gender identity. Four approaches seem especially relevant to a gender analysis of secularization.

First of all, feminist theology tends, to a great extent, to develop mainly within monotheistic traditions (Christianity, Islam, Judaism): the key issues are the re-reading of the holy texts from a feminist perspective and the exploring of creative strategies of "resistance" (among recent publications, see Barlas, 2002; Borresen, 2009; Briggs and Fulkerson, 2011; Henriques and Toldy, 2012; Ruether, 2007; Kamitsuka, 2007; Vuola, 2011; Zorzi, 2014). Contemporary feminist theology views the notions of 'God', 'Christ', and 'Church' as symbolic places around which religious communities build their faith and practices, i.e., as the basic notions, or elaborate forms of symbolic knowledge, underlying such communities (Vuola, 2009: 220). Keeping this in mind, the tension in the relationship between religion and women's rights is understood more as a historical contingency than an irreconcilable difference.

A second particularly significant field of study is the analysis of female devotion. The studies on spiritual movements or on New Religious Movements testify to the variety of experiences and to the ways of building and using sexual identity and gender relationships (Fedele, 2013; Fedele and Knibbe, 2013) as well as of exploring the female dimension of spirituality (Sointu and Woodhead, 2008) ${ }^{5}$. Other studies focus instead on the forms of female religiosity and the role of women and men in monotheistic and traditional religions, especially in conservative and fundamentalist religious

\footnotetext{
5 The use of 'spirituality' as an analytical category is debatable - and some scholars prefer to use the phrase 'lived religion', without assuming an implicit difference between institutionalized religiosity and individual, less structured, devotion (see Hall, 1997).
} 
forms, showing that there exist various types of agency and power for women (Deeb, 2006; Sudda, 2010; Mahmood, 2005). This second field of studies sheds light on the construction of the religious female subject in a secular age.

The third important trend in the literature involves studies within feminism or on feminism. In the former case, some feminists involved in forms of alternative spirituality analyze, from the point of view of gender studies, the deconstructive and generative power of a number of religious practices, such as heresy and profanation, in relation to male and female identity (Starhawk, 1999). In the latter case, studies on religious feminism rethink the relationship between female emancipation, women's rights, agency and religious forms. Studies of womanism, black feminism and Islamic feminism are particularly interesting in that they critically re-read European and North-American feminism from a post-colonial point of view. With regard to Islamic feminism in particular, female academics like Gole (2000), Ahmed (1992), Yamani (1996) and Mir-Housseini (1999) address - although from different perspectives - the relationships between religion and women's agency, showing that a feminism deeply-rooted in religion does exist. In her excellent reconstruction, Stéphanie Latte Abdallah recognizes three different traditions of Islamic feminism: a critical theology movement, formed mainly by female academics, which offers a universalistic analysis and an Islamic feminism that amounts to a "universal, post-identity, hybrid and certainly post-colonial feminism" (2013:222); a second current of religious feminist activists, which adopts a pragmatic activist perspective tightly linked to citizenship and which firmly criticizes laws that are seen as discriminatory against women; and a third movement made up of exponents of political Islam, engaged in the defense of women's rights in the public sphere while valuing the role of women with regard to morals and family life.

Lastly, gender and queer studies of religion analyze the construction of gender and sexual identities and practices of resistance and negotiation within religious traditions (Althaus-Reid, 2003; Loughlin, 2007; Browne et al., 2010; Schippert, 2011). We can identify three types of contributions. A relevant part of such studies focus on the relationships between sexual orientation and religious practices, identity, and beliefs (Wilcox, 2012 and 2009), for example by analyzing homosexuality in several religious traditions (Bergeaud-Blackler, 2013). Another relevant focus concerns the analysis of the construction of gendered subjects and gender differences in religions (see, for example, the recent studies on the construction of the male subject - Krondorfer, 2009; Sawyer, 2004). A third type of contributions use a queer perspective to analyze the complex and manifold intertwining of 
religious and gender identity, especially with regard to "intimate" citizenship (Plummer, 2003), that is, all aspects related to the right to make an individual choice of one's body, values, romantic relationship and sexual and gender identities (see, for example, the collective volume Queering Religion, Religious Queers, Taylor, 2014). These studies support the questioning not just of the binary constructions of gender identity (male/female) and sexual orientation (hetero-, homo-, bi-sexual), but also of the binary construction of the religious $\mathrm{v}$. secular subject, making room for a more nuanced and consistent analysis of the social and political implications of these binary frames. Broadly speaking, these studies call into question the implicit dichotomy between religion and sexual rights, showing how "feminists and queer activists cannot be simply secular, or be secular in a simple or self-evident sense" (Braidotti, 2008: 4), because the - secular society in which they live is the same society that limits their emancipation. At the same time, they suggest a different analytical perspective, based on the intersectional subject rather than binary categorizations.

The analysis of the literature on women, gender, and religion highlights four important elements. First, the fight for women's rights does not evolve solely within a process of secularization, as is clearly shown by the experiences of religious feminism as well as by feminist and womanist theologies. Second, female emancipation from subordinate or unequal relationships is not exclusively related to forms of political agency; there are several forms of agency, even within religious traditions, and the role of women in religion is a complex and diverse one. Third, a secular context does not guarantee rights and self-determination; the fight of historical feminism and the more recent fight for rights on the part of LGBT movements show that a secular state does not automatically guarantee full citizenship for all its inhabitants. Fourth, an analysis that is based on practices of identity (gender, sexual, religious/secular) rather than on categorized subjects may be more effective and consistent for the analysis of the role of religion in contemporary societies.

\section{The Paradox of Women in Secularism: Public, Private and Agency}

If on the one hand it is true that there is no necessary relationship between secularization and gender equality, on the other it is also true that women's rights have thrived prevalently in secular contexts and that gender equality plays a central role among the values of secularization in the narrative of the contemporary. In this sense - as is often the case - considering 'women' in the analysis points to a paradox: women have been 'excluded' from the secularization process, but today they are the 'champions' of that process. 
In particular, the women's rights movement has contributed to reformulating the borders between the public and the private, both in spatial and symbolic terms. The female body is the place where the contradictions between public and private (it is sufficient it to think of the battle over abortion, which immediately projects the female body into a political dimension) and between the secular and the religious (with the body robed in - or disrobed of - religious symbols) are incarnated. It is, furthermore, a spatialized body, which embodies the experiences of the boundaries, the thresholds, and the forbidden space. According to some readings, the questioning of the boundaries between public and private has also contributed to the reformulation of the role of religion in the public, permeable and contemporary sphere (Brown, 2001). The literature, in particular the feminist literature, concerning the reinterpretation of symbolic and spatial boundaries between the public and the private is well known. However, the sociology of religion too has dealt with the redefinition of the boundaries between the public and the private within religious traditions. For example, several studies have explored female religious space as a 'third space', located between the public and the private, which becomes concrete in the church (Morgan, 2002) or in the social and mass media (Lövheim, 2013). Other studies have focused their attention on the forms of composition, re-composition and negotiation of public and private space in alternative (Utriainen and Salmesvuori, 2014) and traditional (Deeb, 2006) spirituality and religiosity. In relation to the tension between private and public-political, both the women's rights movement and feminist literature have dealt extensively with the categories of subjectivity and, especially since the '90s, with agency (Braidotti, 2003; Mann, 1994), which is closely related to the metanarrative of secularization (Mack, 2003): women's capacity to be socially and politically active subjects also hinges on their capacity to determine themselves and thus on the acquisition of the material and symbolic resources that are necessary to make that self-determination possible. The affirmation of female subjectivity in secularized societies started with the questioning of assigned roles and included emancipation from a symbolic universe that relegates women to the role of wives and mothers. In this view, it is clear that conceiving of female subjectivity within a symbolic religious universe raises a series of questions, as Bracke points out (2008a). The battle for women's rights, for instance, led to a redefinition of motherhood: following the claim of women's citizenship in relation to their social function as mothers, the feminist movement (albeit with many internal differences) redefined citizenship in relation to full ownership of the body and to self-determination, including with regard to motherhood 
choices (Allen, 2005). In this respect, the battle over abortion is an example of the battle for full female citizenship - which, in this case, entails full ownership of the body but also leads to the questioning of a liberal conception of citizenship that is founded on disincarnated and decontextualized individuals (Benhabib, 2002) and incapable of addressing relationships of dependence, both symbolic and economic (Fraser and Gordon, 1994; Pitch, 1998). The female debate concerning citizenship and rights is manifold and does not fall within the scope of this paper (see, for example, Friedman, 2005), however, it is important to stress the critique of the liberal conception of universalism and of its embeddedness in individualism and property. This is a critique promoted by feminists - especially liberal ones - which has led to a wide reflection on how to account for difference in a political sense (Pateman, 1970). While some invite us to rethink the liberal foundations of citizenship to find equal forms of participation (Benhabib, 1992 and 1994; Phillips, 2009), other lines of thinking propose forms of institutionalization of heterogeneity (Young, 2003; Mouffe, 1995; Scott, 1997). In the analysis of how democratic citizenship can account not only for sexual difference, but also for all the various possible differences (heterogeneity), the issue of religious difference proves to be a key point: the grammar of political participation in contemporary democracies struggles to accommodate a role for religion (Habermas, 2008) and - often - excludes it (Mouffe, 2005 and 2013) by erecting a dichotomy between the 'religious' and the 'political' subject.

Discussions of the Muslim 'veil', whether it can or cannot be defined as a choice, are a clear example of these potential contradictions (Bilge, 2010). ${ }^{6}$ Within feminism, the debate has developed above all around the publication of Susan Moller Okin's well-known essay "Is Multiculturalism Bad for Women?" (1999; see also Okin, 1998), which triggered an intense discussion on the relationship between feminism and multiculturalism (for a reconstruction, see Volpp, 2001; Ponzanesi, 2007) and whose key points had already been extensively identified by post-colonial feminism (see, for example Mohanty, 1984; Yegenoglu, 1998). When analyzing the public and academic feminist debate about why Muslim women wear a veil, Sirma Bilge identifies two keys to the discourse: false consciousness, which is incapable of seeing oppression, or subversive and resistant use. The religious motive, on the other hand, is often underestimated. When these issues are addressed, the implicit presumption is often - to use Anne

\footnotetext{
${ }_{6}$ The debate is naturally a wide and complex one and concerns post-colonialism as much as feminism. In this paper, I will only briefly outline the main points that are relevant to my discussion.
} 
Phillips' synthesis - that "'They' have cultural traditions; 'I' have moral values" (2009: 31; on the construction of the 'subject' see Spivak, 1988).

In the light of this debate, which also witnesses unprecedented alliances between feminism and conservative and anti-Muslim positions (like those of Ayaan Hirsi Ali and Oriana Fallaci, to name but two; see Cousin and Vitale, 2012 and 2014), several feminist scholars reinterpret the notion of agency from a post-secular perspective, insofar as they question the concept of secularization. As Talal Asad (2003) points out, the epistemic form of modern (liberal, secular) subjectivity entails a strong emphasis on individual agency: in fact, the theoretical narrative of the construction of modernity is closely linked to the separation of the political from the religious sphere and to the emancipation of the individual vis-à-vis 'assigned roles' in order to be free to build an autonomous political subjectivity. In this perspective, Asad continues, religious agencies are, as such, 'defective' forms of agency, because individual choices are based on what lies outside the self - the symbolic and religious universe from which emancipation is needed. The problematic role of religion in the grammar of democratic participation is particularly complex considering the double challenge of building female subjectivity in the political sphere and the religious sphere. Full citizenship necessarily implies the acknowledgement of full agency and liberation - also - from religion: Saba Mahmood, for example, points out how, in Western feminist thought, agency is closely linked to the concept of resistance and the assertion of one's own rights 'against' tradition and social norms (2005). As a consequence, recognizing religious agency as being valid is, in this view, extremely difficult: to use the words of the feminist theologian Elina Vuola, "The questions are can there be agency and empowerment within structures of power, and how can scholars assess this agency without downplaying either the weight of religious sexism or women's possibilities for change?" (2009: 218). Braidotti points out that "political agency need not be critical in the negative sense of oppositional and thus may not be aimed solely or primarily at the production of counter-subjectivities" (2008: 2). In this perspective, Mahmood's proposal to redefine the category of agency in relation to specific grammars - in this case, in relation to religious grammars - and to show female agency not only as reactive, emancipatory, combative and subversive, but also, simply, as active, seems particularly interesting (Mahmood, 2005; see Bracke, 2008a). Agency, that is, the possibility of a non-subaltern action and voice, could be defined based on the contexts within which it is situated or the power relations within certain grammars - while acknowledging the legitimacy of the plurality of these political grammars. 


\section{Conclusion: Gender, Secularization and Citizenship - Political Subjectivity}

This paper aimed at drawing an introductory map of the gendered analyses of secularism and secularization, pointing out their relevance for the analysis of the role of religion in contemporary societies: without specifically joining the conversation, the primary goal was to provide some coordinates in the growing literature on the topic.

In the field of sociology of religion, the gender reading of the process of secularization and of the category of secularism opens up interesting directions for research and analysis in relation to the construction of analytical categories. The understanding of the secularization process has been erected around the analysis of a long-term process primarily linked to the male experience. First of all, the analysis of the female religious experience questions the decline of religiosity - and the tools used to measure it. Secondly, it offers a further critique of the thesis on the privatization of religion - 'private space' is complex, articulated and plural, and boundaries are permeable and full of political significance, engendering multiple and diverse buffer zones. Finally, a specific analysis of the experience of the corporeality of female religiousness, which physically and symbolically crosses the boundaries between the spheres, questions the 'secular' construction of the category of agency and political citizenship and suggests that the analysis of the articulation of religion and politics on an individual level can offer an interesting perspective for the conceiving (and recognizing) of the pluralism of contemporary societies.

In the field of empirical analysis of religion-related topics, the gendered sociology of secularism offers an interesting perspective for a deeper and more complex analysis of contemporary debates involving the female body. The issue of the Muslim veil, as it has evolved especially in France, throws light on the physical and spatial dimension of the boundaries between the private and the public (political), as incarnated in the female body. The religious body cannot physically access a number of (public, secular) spaces and the religiously robed body is the materialization of the absence of agency and, thus, of the impossibility of full political citizenship. At the same time, the female body is central to the debate concerning reproduction, since it poses the question of who has the right and the power to decide on reproductive issues. In this case, too, it is in the female body that the boundaries between the political, the private and the religious become concrete and the female body is also where the battle between different forms of authority, across the two spheres - political/private (is decision power individual or could/should a higher authority intervene under certain circumstances?) and political/religious (if so, which authority?) - is being fought. Accordingly, 
the analysis of the forms of power, of gender relations, of the construction of male and female identities and of the degrees of freedom of religious creativity in relation to a higher authority which evolves within religious communities, as well as the analysis of how, in the context of female religious experience, women are negotiating their own religious and political identity, can offer interesting points of inspiration for a public reflection that promotes full political citizenship for women without exclusion.

From a theoretical perspective, the reflections on female agency and religious agency focus on the problematic elements in the contemporary political debate: what are the forms of a radical democracy that is capable of guaranteeing a voice and subjectivity to excluded subjects? How can we uproot the implicit forms of power? What forms of the debate give political legitimacy to incommensurable values while still allowing them to interact and coexist? Of particular importance in this regard are the approaches that focus on citizenship as a practice (Oleksy, 2009) and treat the subjects as part of a network of dependencies, both material and symbolic, and of multiple systems that define identity, in an intersectional logic (Crenshaw, 1989). In this sense, de-essentializing differences by separating them from their assigned statuses (biological, cultural, religious, national) makes it possible to overcome binary constructions and to consider their transformational and procedural aspects. In particular, studying the concrete practices of political subjectivity by taking the positions of the actors seriously and without imposing a normative agency model makes it possible to focus one's attention on the structural elements that can ensure actual democratic agency. In this perspective, and as many studies have shown, political institutions have a central role not only in the construction of the legitimate political subject, but also in the construction of political and value controversies in which ultimately irreconcilable positions stand opposed (Ozzano and Giorgi, 2016).

To conclude, the analyses concerning the march for women's rights prove that not only is there no necessary relationship between secularization and women's rights, but the battle for women's rights has contributed to the reformulating of the process of secularization. The analyses of female religious experience show that the category of secularization falls short of accounting for the female experience and interrogate the issue of agency as a key element of contemporary political subjectivity. In this view, gender analysis makes it possible, first of all, to reformulate the category of secularization and to make it more complex and sensitive; secondly, it offers the possibility of a fresh perspective on how we conceive of contemporary democracy.

Revised by João Paulo Moreira 


\section{References}

Abdallah, Stéphanie Latte (2013), "Féminismes islamiques à l'heure révolutionnaire: normes, genre et démocratie”, in Florence Rochefort; Maria Eleonora Sanna (eds.), Normes religieuses et genre. Mutations, résistances et reconfiguration XIX-XXI siècle. Paris: Armand Colin, 217-230.

Ahmed, Leila (1992), Women and Gender in Islam: Historical Roots of a Modern Debate. New Haven: Yale University Press.

Allen, Ann Taylor (2005), Feminism and Motherbood in Western Europe, 1890-1970: The Maternal Dilemma. New York: Palgrave MacMillan.

Althaus-Reid, Marcella (2003), The Queer God. London/New York: Routledge.

Asad, Talal (2003), Formations of the Secular: Christianity, Islam, Modernity. Stanford, California: Stanford University Press.

Aune, Kristin; Sharma, Sonya; Vincett, Giselle (eds.) (2008), Women and Religion in the West: Challenging Secularization. Aldershot: Ashgate.

Bhargava, Rajeev (ed.) (1998), Secularism and its Critics. Delhi: Oxford University Press.

Barlas, Asma (2002), 'Believing Women' in Islam: Unreading Patriarchal Interpretations of the Qur' n. Austin: University of Texas Press.

Baubérot, Jean Paul; Milot, Micheline (2011), Laïcités sans frontières. Paris: Seuil.

Beckford, James (1996), "Postmodernity, High Modernity and New Modernity: Three Concepts in Search of Religion”, in Kieran Flanagan; Peter C. Jupp (eds.), Postmodernity, Sociology, and Religion. London: Macmillan, 30-47.

Beckford, James (2000), "Start Together and Finish Together: Shifts in the Premises and Paradigms Underlying the Scientific Study of Religion”, Journal for the Scientific Study of Religion, 39(4), 481-495.

Benhabib, Seyla (1992), Situating the Self. Gender, Community and Postmodernism in Contemporary Ethics. Hoboken: Wiley.

Benhabib, Seyla (1994), "In Defense of Universalism. Yet Again! A Response to Critics of Situating the Self”, New German Critique, 62, 173-189.

Benhabib, Seyla (2002), The Claims of Culture: Equality and Diversity in the Global Era. Princeton: Princeton University Press.

Bergeaud-Blackler, Florence (2013), "Normes islamiques de sexualité: l'émergence des 'gay muslims' en Europe”, in Florence Rochefort; Maria-Eleonora Sanna (eds.), Normes religieuses et genre. Mutations, résistances et reconfiguration XIX-XXI siècle. Paris: Armand Colin, 231-244.

Bilge, Sirma (2010), "Beyond Subordination vs. Resistance: An Intersectional Approach to the Agency of Veiled Muslim Women”, Journal of Intercultural Studies, 31(1), 9-28.

Borresen, Kari Elisabeth (2009), "Modelli di genere nella tradizione cristiana", in Giovanni Filoramo (ed.), Le religioni e il mondo moderno, vol. IV. Torino: Einaudi, 319-340. 
Bracke, Sarah (2008a), "Conjugating the Modern/Religious, Conceptualizing Female Religious Agency. Contours of a 'Post-secular' Conjuncture”, Theory, Culture \& Society, 25(6), 51-67.

Bracke, Sarah (2008b), “'Real' Islam in Kazan: Reconfiguring the Modern, Knowledge and Gender”, in Kristin Aune, Sonya Sharma and Giselle Vincett (eds.), Women and Religion in the West: Challenging Secularization. Aldershot: Ashgate, 183-194.

Braidotti, Rosi (2003), Metamorphosis: Towards a Material Theory of Becoming. Cambridge: Polity Press.

Braidotti, Rosi (2008), "In Spite of the Times. The Postsecular Turn in Feminism”, Theory, Culture E Society, 25(6), 1-24.

Briggs, Sheila; Fulkerson, Mary McClintock (eds.) (2011), Oxford Handbook of Feminist Theology. Oxford: Oxford University Press.

Brown, Callum (2001), The Death of Christian Britain. New York: Routledge.

Browne, Kath; Munt, Sally Rowena; Yip, Andrew K. T. (eds.) (2010), Queer Spiritual Spaces: Sexuality and Sacred Spaces. Farnham/Burlington: Ashgate.

Casanova, José (1994), Public Religions in the Modern World. Chicago: University of Chicago Press.

Castelli, Elizabeth (ed.) (2001), Women, Gender, Religion: A Reader. New York: Palgrave.

Chaves, Mark (1994), "Secularization as Declining Religious Authority”, Social Forces, 72(3), 749-774.

Chewning, Susannah Mary (ed.) (2005), Intersections of Sexuality and the Divine in Medieval Culture: The Word Made Flesh. Aldershot: Ashgate.

Cousin, Bruno; Vitale, Tommaso (2012), "Italian Intellectuals and the Promotion of Islamophobia after 9/11”, in George Morgan; Scott Poynting (eds.), Global Islamophobia: Muslims and Moral Panic in the West. Aldershot: Ashgate, 47-66.

Cousin, Bruno; Vitale, Tommaso (2014), "Le magistère intellectuel islamophobe d'Oriana Fallaci. Origines et modalités du succès italien de la 'Trilogie sur l'Islam et sur l'Occident' (2001-2006)", Sociologie, 5(1), 61-79.

Crenshaw, Kimberle (1989), "Demarginalizing the Intersection of Race and Sex: A Black Feminist Critique of Antidiscrimination Doctrine, Feminist Theory and Antiracist Politics", The University of Chicago Legal Forum, 140, 139-167.

Crook, Margaret Brackenbury (1964), Women and Religion. Boston: Beacon Press.

Daly, Mary (1973), Beyond God the Father. Toward a Philosophy of Women's Liberation. Boston: Beacon Press.

Deeb, Lara (2006), An Enchanted Modern: Gender and Public Piety in Shi'i Lebanon. Princeton/Oxford: Princeton University Press.

Dobbelaere, Karl (1985), "Secularization Theories and Sociological Paradigms: A Reformulation of the Private-Public Dichotomy and the Problem of Societal Integration", Sociological Analysis, 46(4), 377-387. 
Fedele, Anna (2013), Looking for Mary Magdalene: Alternative Pilgrimage and Ritual Creativity at Catholic Shrines in France. Oxford: Oxford University Press.

Fedele, Anna; Knibbe, Kim (eds.) (2013), Gender and Power in Contemporary Spirituality. Ethnographic Approaches. New York: Routledge.

Ferrara, Alessandro (2009), "The Separation of Religion and Politics in a Post-secular Society", Philosophy \& Social Criticism, 35(1-2), 77-91.

Fiorenza, Elizabeth Schüssler (1983), In Memory of Her: A Feminist Theological Reconstruction of Christian Origins. New York: Crossroads.

Forcades, Teresa (2015), La teologia femminista nella storia. Il ruolo delle donne e il diritto all'autodeterminazione femminile. Roma: Nutrimenti.

Fraser, Nancy; Gordon, Linda (1994), “A Genealogy of Dependency: Tracing a Keyword of the U.S. Welfare State”, Signs, 19(2), 309-336.

Friedman, Marilyn (ed.) (2005), Women and Citizenship. Oxford: Oxford University Press. Gole, Nilufer (2000), "Snapshots of Islamic Modernities," Daedalus, 129(1), 91-117. Habermas, Jürgen (2008), “Notes on Post-Secular Society”, New Perspectives Quarterly, 25(4), 17-29.

Hall, David (ed.) (1997), Lived Religion in America: Toward a History of Practice. Princeton: Princeton University Press.

Heelas, Paul; Woodhead, Linda; Seel, Benjamin (eds.) (2005), The Spiritual Revolution: Why Religion is Giving Way to Spirituality. Oxford: Blackwell.

Henriques, Fernanda; Toldy, Teresa (eds.) (2012), Mulheres que ousaram ficar. Contributos para a teologia feminista. Porto: Letras \& Coisas.

Herzog, Hanna; Braude, Ann (eds.) (2009), Gendering Religion and Politics. Untangling Modernities. New York: Palgrave.

hooks, bell (1990), Yearning: Race, Gender and Cultural Politics. Toronto: Between the Lines. Höpflinger, Anna-Katharina; Lavanchy, Anne; Dahinden, Janine (2012), "Introduction: Linking Gender and Religion”, Women's Studies: An Interdisciplinary Journal, 41(6), 615-638.

Kamitsuka, Margaret (2007), Feminist Theology and the Challenge of Difference. Oxford: Oxford University Press.

King, Ursula (ed.) (1995), Religion and Gender. Hoboken: Wiley.

King, Ursula; Beattie, Tina (eds.) (2004), Religion, Gender and Diversity: Cross-Cultural Perspectives. London: Continuum.

Korte, Anne-Marie (2011), "Openings: A Genealogical Introduction to Religion and Gender", Religion and Gender, 1(1), 1-17.

Krondorfer, Björn (ed.) (2009), Men and Masculinities in Christianity and Judaism. London: SCM Press.

Lorde, Audre (1984), Sister Outsider. Trumansberg, New York: Crossing Press.

Loughlin, Gerard (ed.) (2007), Queer Theology: Rethinking the Western Body. Malden/ /Oxford: Blackwell. 
Lövheim, Mia (2013), Media, Religion and Gender: Key Issues and New Challenges. Abingdon/New York: Routledge.

McAdam, Doug; Tarrow, Sidney; Tilly, Charles (2001), Dynamics of Contention. Cambridge: Cambridge University Press.

Mack, Phyllis (2003), "Religion, Feminism, and the Problem of Agency: Reflections on Eighteenth Century Quakerism”, Signs, 29(1), 149-177.

Mahmood, Saba (2005), Politics of Piety: The Islamic Revival and the Feminist Subject. Princeton, New Jersey: Princeton University Press.

Mann, Patricia S. (1994), Micro-politics: Agency in a Postfeminist Era. Minneapolis: University of Minnesota Press.

McLaughlin, Eleanor (1975), "The Christian Past: Does it Hold a Future for Women?", Anglican Theological Review, 57, 36-56.

Mir-Hosseini, Ziba (1999), Islam and Gender. The Religious Debate in Contemporary Iran. Princeton: Princeton University Press.

Mohanty, Chandra Talpade (1984), "Under Western Eyes: Feminist Scholarship and Colonial Discourses”, Boundary 2, 12(3)/13(1), 333-358.

Morgan, Sue (ed.) (2002), Women, Religion and Feminism in Britain, 1750-1900. Basingstoke: Palgrave Macmillan.

Morin, Karen M.; Guelke, Jeanne Kay (eds.) (2007), Women, Religion \& Space: Global Perspectives on Gender and Faith. Syracuse, New York: Syracuse University Press. Mouffe, Chantal (1995), "Feminism, Citizenship, and Radical Democratic Politics", in Linda Nicholson; Steven Seidman (eds.), Social Postmodernism. Beyond Identity Politics. Cambridge: Cambridge Universtiy Press, 315-331.

Mouffe, Chantal (2005), On the Political. New York: Routledge.

Oleksy, Elzbieta Helena (ed.) (2009), Intimate Citizenships. Gender, Sexualities, Politics. New York: Routledge.

Okin, Susan Moller (1998), "Feminism and Multiculturalism: Some Tensions", Ethics, 108(4), 661-684.

Okin, Susan Moller (1999), "Is Multiculturalism Bad for Women?", in Joshua Cohen; Matthew Howard; Martha Nussbaum (eds.), Is Multiculturalism Bad for Women? Princeton: Princeton University Press, 7-23.

Ozzano, Luca; Giorgi, Alberta (2016), European Culture Wars and the Italian Case. Which Side Are You On? Abingdon: Routledge.

Pateman, Carol (1970), Participation and Democratic Theory. Cambridge: Cambridge University Press.

Phillips, Anne (2009), Multiculturalism without Culture. Princeton: Princeton University Press.

Pitch, Tamar (1998), Un diritto per due. Milano: Il Saggiatore.

Ponzanesi, Sandra (2007), "Feminist Theory and Multiculturalism”, Feminist Theory, 8(1), 91-103. 
Plummer, Ken (2003), Intimate Citizenship: Private Decision and Public Dialogues. Seattle: University of Washington Press.

Rochefort, Florence (ed.) (2007a), Le pouvoir du genre. Lä̈cités et religions 1905-2005. Toulouse: PUM.

Rochefort, Florence (2007b), “Ambivalences laïques et critiques féministes”, in Florence Rochefort; Maria-Eleonora Sanna (eds.), Le pouvoir du genre. Laïcités et religions 1905-2005. Toulouse: PUM, 65-82.

Ruether, Rosemary Radford (ed.) (2002), Gender, Ethnicity and Religion: Views from the Other Side. Minneapolis: Fortress Press.

Ruether, Rosemary Radford (ed.) (2007), Feminist Theologies: Legacy and Prospect. Minneapolis: Fortress Press.

Saiving, Valerie (1979), "The Human Situation: A Feminine View”, in Carol Christ; Judith Plaskow (eds.), Womanspirit Rising. A Feminist Reader in Religion. New York: Harperone, 25-42.

Sawyer, Deborah (2004), “Biblical Gender Strategies: The Case of Abraham's Masculinity”, in Ursula King; Tina Beattie (eds.), Religion, Gender and Diversity: Cross-Cultural Perspectives. London: Continuum, 162-171.

Schippert, Claudia (2011), "Implications of Queer Theory for the Study of Religion and Gender: Entering the Third Decade”, Religion and Gender, 1(1), 66-84.

Scott, Joan W. (1997), Only Paradoxes to Offer. French Feminists and the Rights of Man. Harvard: Harvard University Press.

Scott, Joan Wallach (2009), "Sexularism”, Ursula Hirschmann Annual Lecture on Gender and Europe. Robert Schuman Centre for Advanced Studies. Accessed on 21.07.2016, at http://cadmus.eui.eu/bitstream/handle/1814/11553/RSCAS_DL_2009_01.pdf.

Sointu, Eeva; Woodhead, Linda (2008), "Spirituality, Gender, and Expressive Selfhood”, Journal for the Scientific Study of Religion, 47(2), 259-276.

Spivak, Gayatri Chakravorty (1988), "Can the Subaltern Speak?”, in Cary Nelson; Lawrence Grossberg (eds.), Marxism and the Interpretation of Culture. Urbana: University of Illinois Press, 271-313.

Stanton, Elizabeth Cady (1895 and 1898), The Woman's Bible. Project Gutenberg. Accessed on 21.07.2016, at https://www.gutenberg.org/ebooks/9880.

Starhawk (1999), The Spiral Dance. San Francisco: Harper Books.

Sudda, Magali Della (2010), "La politique malgré elles. Mobilisations féminines catholiques en France et en Italie (1900-1914)”, Revue française de science politique, 60(1), 36-60.

Taylor, Charles (2007), A Secular Age. Harvard: Harvard University Press.

Taylor, Yvette (ed.) (2014), Queering Religion, Religious Queers. New York: Routledge.

Utriainen, Tehri; Salmesvuori, Päivi (eds.) (2014), Finnish Women Making Religion: Between Ancestors and Angels. New York: Palgrave MacMillan.

Volpp, Leti (2001), “Feminism Versus Multiculturalism”, Columbia Law Review, 101(5), 1181-1218. 
Vuola, Elina (2009), “Patriarchal Ecumenism, Feminism, and Women's Religious Experiences in Costa Rica”, in Hanna Herzog; Ann Braude (eds.), Gendering Religion and Politics: Untangling Modernities. New York: Palgrave Macmillan, 217-238.

Vuola, Elina (2011), “La Morenita on Skis: Women's Popular Marian Piety and Feminist Research of Religion”, in Sheila Briggs; Mary McClinton Fulkerson (eds.), The Oxford Handbook of Feminist Theology. Oxford: Oxford University Press, 494-524.

Walker, Alice (1983), In Search of our Mothers' Gardens: Womanist Prose. San Diego: Harcourt Brace Jovanovich.

Wilcox, Melissa M. (2009), Queer Women and Religious Individualism. Bloomington: Indiana University Press.

Wilcox, Melissa M. (2012), “'Spiritual Sluts': Uncovering Gender, Ethnicity, and Sexuality in the Post-Secular”, Women Studies, 41(6), 639-659.

Wohlrab-Sahr, Monika (2011), “'Forced' Secularity? On the Appropriation of Repressive Secularization", Religion and Society in Central and Eastern Europe, 4(1), 63-77.

Wohlrab-Sahr, Monika; Burchardt, Marian (2012), "Multiple Secularities: Towards a Cultural Sociology of Secular Modernities", Comparative Sociology, 11, 875-909. Woodhead, Linda (2001), "Feminism and the Sociology of Religion: From Gender-blindness to Gendered Difference”, in Richard K. Fenn (ed.), The Blackwell Companion to Sociology of Religion. Maldon, MA: Blackwell, 67-84.

Yamani, Mai (ed.) (1996), Feminism and Islam: Legal and Literary Perspectives. Berkshire: Ithaca Press.

Yegenoglu, Meyda (1998), Colonial Fantasies. Towards a Feminist Reading of Orientalism. Cambridge: Cambridge University Press.

Young, Iris Marion (2003), "Polity and Group Difference: A Critique of the Ideal of Universal Citizenship”, in Derek Matravers and Jon Pike (eds.), Debates in Contemporary Political Philosophy. An anthology. New York: Routlegde, 219-238. Zorzi, Benedetta Selene (2014), Al di là del 'genio femminile'. Donne e genere nella storia della teologia cristiana. Roma: Carocci.

Artigo recebido a 30.07.2015

Aprovado para publicação a 06.05.2016

\author{
Alberta Giorgi \\ Centro de Estudos Sociais, Universidade de Coimbra \\ Colégio de S. Jerónimo, Largo D. Dinis, Apartado 3087, 3000-995 Coimbra, Portugal \\ Contact: albertagiorgi@ces.uc.pt
}




\section{Género, religião e ação política: cartografia da área}

Através de uma revisão de caráter introdutório da literatura, este artigo visa cartografar as análises das categorias secularismo e secularização desenvolvidas a partir de uma perspetiva de género e de um ponto de vista sociológico, com o objetivo de fornecer algumas coordenadas e referências bibliográficas, bem como de mostrar as implicações teóricas e analíticas deste tipo de estudos do secularismo em relação às gramáticas da democracia contemporânea. Em primeiro lugar, explora-se a forma como uma análise levada a cabo sob a perspetiva de género contribui para redefinir os conceitos analíticos de secularismo e secularização. Em segundo lugar, destacam-se os contributos dos estudos sobre as mulheres, de género e queer para a análise do secularismo e da religião. Em terceiro lugar, realçam-se as tensões entre a intervenção política das mulheres e da religião, mostrando como e em que medida o debate em curso no âmbito da sociologia da religião é, de facto, de grande importância para os estudos sociológicos atuais.

Palavras-chave: direitos da mulher; estudos de género; política; secularização; sociologia da religião.

\section{Genre, religion et action politique: cartographie du secteur}

Par le truchement d'une révision au caractère préliminaire de la littérature, cet article a pour but de cartographier les analyses des catégories de sécularisme et de sécularisation développées à partir d'un point de vue de genre et d'une perspective sociologique, dans le but de fournir quelques coordonnés et références bibliographiques, tout autant que de montrer les implications théoriques et analytiques de ce type d'études du sécularisme para rapport aux grammaires de la démocratie contemporaine. Tout d'abord, nous cherchons à savoir comment une analyse menée d'un point de vue de genre contribue à redéfinir les concepts analytiques de sécularisme et de sécularisation. Ensuite, nous mettons en relief des études sur les femmes, de genre et queer pour l'analyse du sécularisme et de la religion. Enfin, nous soulignons les tensions existant entre l'intervention politique des femmes et la religion, en démontrant comment et dans quelle mesure le débat en cours dans le cadre de la sociologie de la religion revêt, de fait, une haute importance pour les études sociologiques actuelles.

Mots-clés: droits de la femme; études de genre; politique; sécularisation; sociologie de la religion. 